\title{
Privileged Testimony of Husband and Wife in California*
}

\section{HISTORY OF THE PRIVILEGES}

The disqualification of husband and wife to testify for or against the other in both civil and criminal cases seems to have been recognized in the common law from the time of Lord Coke. ${ }^{1}$ Certain exceptions were recognized by reason of necessity, such as crimes of personal violence by the husband against the wife. ${ }^{2}$

Dean Wigmore states the common law rule in the light of a distinction between a privilege of one spouse not to testify against the other, and absolute incompetency of one spouse to testify for the other. ${ }^{3}$ But the rule is generally conceded to have been one of absolute incompetency in either situation. 4

"The validity of this misguided rule of the common law could not long have remained unquestioned, as soon as any discussion was raised regarding the propriety of the general rules for competency of witnesses."5 From 1840 to 1870 legislation by degrees removed the disqualification in England and in the United States. ${ }^{6}$

Most of the states, while abohshing incompetency of husband and wife, retain the rule in the form of a privilege as to testimony against the

*Written for a seminar on Problems in the Administration of Civil Justice conducted by Professor Clarke B. Whittier, School of Law, Stanford University.

11 WIGMORE, EvIDENCE (2d ed. 1923) §600; 4 ibid. \$2227.

21 ibid. \$612; 4 ibid. \$2239.

31 ibid. \$601; 4 ibid. §§2227, 2242; 5 ibid. \$2334.

4 (1920) 33 HiRv. L. Rev. 873; (1928) 13 Iowa L. REv. 481 ; 40 Cyc. 2210; 6 ENCX. of Evm. $845 ; 28$ R. C. L. 479: "Though there are early cases which give support to a contrary theory, no apparent distinction seems to have been made between this incompetency as a matter of disability and as a nuatter of privilege. On the contrary, the mcompetency was absolute and did not rest on privilege. The consent of either party or both parties is entirely immaterial."

Statements of the rule im California: "On this as on nearly every other subject to which the Codes relate, they are simply declaratory of what the law would be if there were no Codes." People v. Langtree (1883) 64 Cal. 256, 259, 30 Pac. $813,814$.

"Subdivision 1 of section 1881 of the Code of Civil Procedure, in disqualifying husband and wife to testify for or against each other, is a declaration of the common law." Estate of Goff (1897) 5 Coffey's Prob. Dec. 432. (Obviously incorrect in its interpretation of the code.)

"The rule of the common law that the wife was absolutely incompetent to testify against her husband has been mnodified in this state so that either spouse may testify with the consent of the other." People v. Singh (1920) 182 Cal. 457, 483, 188 Pac. 987, 998.

51 WIGMORE EVIDENCE (2d ed. 1923) §602.

61 ibid. \$602; 5 ibid. \$2333. 
spouse, and all provide for the privilege as to confidential communications. ${ }^{7}$ The existence of this latter privilege as to confidential communications was only perceived when the common law disqualification was proposed to be abolished or modified. Hence its nature and scope were first outlined in statutory provisions of the reform period, 1840 to $18700^{\mathrm{s}}$

\section{In California}

The common law rule of incompetency and of privileged communications was formulated in section 395 of the Practice Act of 1851, which excepted an action or proceeding by one spouse against the other. This disability was held not to be removed by a statute allowing parties to testify. ${ }^{9}$

In 1863 husband and wife were made competent witnesses "tlie same as any other witnesses" except in actions for divorce, without any express privilege. Also neither was competent to disclose any communication made by the other during marriage. ${ }^{10}$ Tluus in none of the situations was there a privilege concerned.

This amendment to the Practice Act was held not to apply in a criminal case. ${ }^{11}$ But in 1866 husband and wife were made competent witnesses in criminal cases either "by consent of both" or in cases of personal violence by one upon the other. ${ }^{12}$

In 1870 the parties were made competent in divorce actions. ${ }^{13}$

With the adoption of the codes in 1872 the privilege of husband and wife in criminal cases was carried over into section 1322 of the Penal Code. Section 1881 of the Code of Civil Procedure, althougli based upon section 395 of the Practice Act, establisled the general privilege of husband and wife as witness for or against tle other, and the privilege as to "any communication made by one to the other during the marriage." Two general exceptions were made: a civil action by one against the other, and a criminal action for a crime by one against the other.

The ill-fated section 1882 of the Code of Civil Procedure was then adopted, providing that one spouse's offering himself as a witness would constitute a waiver of both privileges, as to that subject on which he offered testimony. This was repealed in $1876 . .^{14}$ In 1901 further provi-

71 ibid. $\S \S 488,620 ; 4$ ibid. $\$ 2245 ; 5$ ibid. \$2333.

85 ibid. \$2333.

9 Cal. Stats. 1861, c. 467 ; Practice Act (1851) \$422. Dawley v. Ayers (1863) 23 Cal. 108. The great weight of authority was contra. 1 WIGMORE, EvDoENCE (2d ed. 1923) \$6113; 4 ibid. \$2245.

10 Cal. Stats. 1863, c. 528; amendment to Practice Act (1851) \$395.

11 People v. McFlynn (1865) 1 Cal. Unrep. 234; People v. Anderson (1864) 26 Cal. 130 semble.

12 Cal. Stats. 1866, c. 64.

13 Cal. Stats. 1870 , c. 188 . Corroboration was required.

14 Code Amendments 1875-6, c. 42. 
sions as to waiver were adopted as section 1882 of the Code of Civil Procedure. ${ }^{15}$ But the whole act was held unconstitutional as an attempted revision without re-enactment and publication at large. ${ }^{16}$ Since then the courts have interpreted the doctrine of waiver without the guidance of express legislation.

In 1907, section 1881, subdivision 1, of the Code of Civil Procedure was brought to its present form by the addition of two further exceptions: an action brought by husband or wife against another person for the alienation of affections of either husband or wife; and an action for damages against another person for adultery committed by either husband or wife. In 1905 evidence of communications between husband and wife had been held inadmissable in a suit by the wife for alienation of the husband's affections. ${ }^{17}$

The statutory exceptions to the privilege in criminal cases have been consistently extended. In 1905 were added to the list actions for bigamy and actions under section 270 of the Penal Code (failure of father to provide child with necessaries)..$^{18}$ Likewise section $266 \mathrm{~g}$ of the Penal Code was adopted, ${ }^{19}$ creating the crime of placing or permitting the placing of one's wife in a house of prostitution, and making the wife a competent witness against her husband in all prosecutions under the section.

In 1907 were added actions for adultery, and actions under section 270a of the Penal Code (non-support of wife).$^{20}$ In 1911 the exceptions under sections 270 and 270a of the Penal Code were clarified by section 270e of the Penal Code. ${ }^{21}$ Also section 1322 was rephrased, and to the old exception of an act of criminal violence by. one upon the other there was added a blanket provision for all criminal actions or proceedings for a crime committed by one against the person or property of the other. ${ }^{22}$ This placed the section in its present form.

In 1911 a statute creating the crime of pimping provided that the female in question should be competent as a witness for or against the accused, or as to any communications with the accused, although she had married the accused before or after the alleged crime.23

15 Cal. Stats. 1901, c. 48.

16 Lewis v. Dunne (1901) 134 Cal. 291, 66 Pac. 478.

17 Humphrey v. Pope (1905) 1 Cal. App. 374, 82 Pac. 223.

18 Cal. Stats. 1905 , c. 568.

19 Cal. Stats. 1905, c. 497.

20 Cal. Stats. 1907 , c. 230 .

21 Cal. Stats. 1911, c. 379.

22 Cal. Stats. 1911, c. 103.

23 Cal. Stats. 1911, c. 15. 


\section{THE LAW OF CALIFORNIA UNDER THE PRESENT CODE}

\section{A. The Privilege as to Testimony by One Spouse \\ For or Against the Other}

\section{In General}

The code provides that, with certain exceptions, "a husband cannot be examined for or against his wife without her consent; nor a wife for or against her husband, without his consent"24 and that "neither husband nor wife is a competent witness for or against the other in a criminal action or proceeding to which one or both are parties, except with the consent of both."25

The first provision is not restricted to civil cases, but its terms (as to the present privilege) applicable to criminal cases, are duplicated and supplemented in section 1322 of the Penal Code, which has been held controlling in criminal cases. ${ }^{26}$ Instances in which the two code provisions differ will be noted as they arise.

The code is to be liberally construed in favor of the admissibility of evidence. ${ }^{27}$

\section{Who is Prohibited as Husband or Wife}

In order for the privilege to apply, the witness must be a lawful spouse ${ }^{28}$ at the time of taking the stand. ${ }^{29}$

The application of the privilege where the marriage is in dispute has not been decided. ${ }^{30}$

24 CaI. Code Civ. Proc. \$1881, subd. 1.

25 CaI. Pen. Code $\$ 1322$.

26 People v. Langtree (1883) 64 Cal. 256, 30 Pac. 813.

27 Estate of Goff (1897) 5 Coffey's Prob. Dec. 432; Mitchell v. Superior Court (1912) 163 Cal. 423, 125 Pac. 1061. See Note (1913) 41 L. R. A. (N. s.) 1213.

28 In People v. Anderson (1864) 26 Cal. 130, under Practice Act (1851) \$395, making husband and wife incompetent for or against each other, a witness was held competent where there was no lawful marriage, although the parties had lived together as husband and wife and had been received in public and in society as such.

Parties to an illicit relationship cannot claim the privilege. People v. Alviso (1880) 55 Cal. 230.

The point whether an Indian and his squaw taken according to Indian custom were to be regarded as husband and wife was raised but not decided in People v. Ketchum (1887) 73 Cal. 635, 15 Pac. 353.

See Note (1905) 6 Ann. Cas. 1021.

29 Divorce ends the privilege. See infria note 64 . Marriage after the crime against the wife brings withm the privilege. See infra note 86 .

30 In Estate of Pnsey (1919) $180 \mathrm{Cal} .368,181 \mathrm{Pac} .648$, the husband claimed a valid marriage to the testatrix. Although the decision of the court was that the divorce was invalid, it was held that under those circumstances a general objection to the testimony of the first wife was not sufficient to raise the question of ber competency. But no opinion was voiced that the objection, if properly made, would not have been sustained; the contrary was rather assumed. Yet this case is cited as not allowing the husband to object where the marriage is disputed, in 4 WIGMore, EVIDENCE (2d ed. 1923) \$2231, note 4. 
The privilege applies in case of a voidable marriage not yet annulled. ${ }^{31}$

\section{What is Prohibited as Testimony}

Otherwise competent evidence of extrajudicial statements made by a spouse to a third person is not excluded as within the privilege. ${ }^{32} \mathrm{~A}$ fortiori, where statements are made by one spouse in the other's presence, they are admissible upon the independent ground of showing the other's assent or reaction to them. ${ }^{33}$

The privilege prevents a spouse from swearing out a complaint against the other spouse in a criminal case. ${ }^{34}$

\section{When Testimony is For or Against the Spouse}

In any case the testimony will be for or against a spouse who is a party to the action..$^{35}$ In a criminal case the privilege applies only in favor of a person for or against whom as a party to the cause the testimony of a husband or wife is offered. ${ }^{36}$ This seems clear on the language of the code. ${ }^{37}$

31 People v. Livingston (1928) 88 Cal. App. 713, 263 Pac. 1036 (error to allow the wife to testify against her husband when annulment decree not yet final); see People v. Souleotes (1915) 26 Cal. App. 309, 310, 146 Pac. 903, 904.

32 People v. Chadwick (1906) 4 Cal. App. 63, 87 Pac. 384 (testimony of the defendant's wife at a former trial for forgery admissible in a prosecution for perjury, "to show the materiality of the husband's evidence"); First National Bank v. De Moulin (1922) 56 Cal. App. 313, 205 Pac. 92 (husband's letters to the plaintiff admissible against the wife).

A dictum to the contrary was contained in People v. Converse (1915) $28 \mathrm{Cal}$. App. 687, 153 Pac. 734, the evidence being excluded as hearsay, however. In People v. Smith (1926) 78 Cal. App. 68, 248 Pac. 261 an exclusion of declarations of a spouse as within the privilege was not disapproved on appeal, though not directly in question. Actually the question was of privileged communications related to the witness by the spouse. People v. Simonds (1861) 19 Cal. 276 (declarations of a spouse excluded solely as hearsay).

See in general 28 R. C. L. 480 (imdirect evidence admissible). Contra: Note (1906) 2 L. R. A. (N. s.) 863.

33 People v. Murphy (1872) 45 Cal. 137; People v. Colombo (1924) $70 \mathrm{Cal}$. App. 489, 233 Pac. 413 (wife's warning to husband on approach of officers hcld admissible).

In the present situation the evidence was allowed at common law, which held declarations of a spouse ordinarily inadmissible, though sometimes on the ground of hearsay. 4 WIGMORE, EvidencE (2d ed. 1923) \$2232.

34 People v. Gregory (1908) 8 Cal. App. 738, 97 Pac. 912 (dictum to the effect that wife's counplaint against husband for crime against their child should have been dismissed). See Note (1905) 6 Ann. Cas. 187.

35 Fitzgerald v. Livermore (1887) 2 Cal. Unrep. 744, 13 Pac. 167 (plaintiff's wife called as witness by defendant; evidence excluded); Marple v. Jackson (1920) 184 Cal. 411, 193 Pac. 940 (husband cannot be called as witness for defendant in an action by the wife to enjom a sale on execution against the husband).

36 In People v. Langtree (1883) 64 Cal. 256, 30 Pac. 813, the spouse unsuccessfully claiming the privilege was charged with the same crime, but by separate information. See 4 WIGMORE, EVIDENCE \$2234.

37 Cax. Pen. Code §1322. 
The rule as to civil cases is probably the same, ${ }^{38}$ but some doubt has been thrown upon the character of one spouse's testimony for or against the estate of the other. ${ }^{39}$

Where both husband and wife are joined, the husband's disclaimer of interest in the subject-matter of the action makes him a nominal party, and he can claim no privilege as to testimony by the wife.40

\section{Exercise of the Privilege}

1. To Whom the Privilege Belongs

a. Civil Cases

By the language of the code $\mathrm{d}^{41}$ the privilege is that of the party spouse alone.

Since the code makes no exception where the other spouse is incapable of consenting, a witness-spouse cannot testify for an insane partyspouse suing by his guardian. ${ }^{43}$

\section{b. Criminal Cases}

The code provides for the consent of both husband and wife in criminal cases. ${ }^{44}$

38 People v. Langtree (1883) 64 Cal, 256, 30 Pac. 813.

39 In Savings Union Bank \& Trust Co. v. Crowley (1917) 176 Cal. 543, 169 Pac. 67 , it was held that an action by deceased spouse's estate against surviving spouse is an action by one spouse against the other, and hence within the code exception to the privilege; communications not privileged. This confirms the view that the wife is testifying against the husband, though he is not a party; but the case will probably not be extended to actions between the estate and a third party.

Metz v. Bell (1902) 7 Cal. Unrep. 41, 70 Pac. 618 semble (wife not competent against husband's estate under Cac. Code Crv. Proc. \$1881, subd. 1.) Contra: Nicoll v. Nicoll (1913) 22 Cal. App. 268, 133 Pac. 1144 (wife competent against husband's estate except as to communications). See 28 R. C. L. 489 ; Note (1917) Ann. Cas. $1917 \mathrm{D} 216$.

40 Johnston v. St. Sure (1921) 50 Cal. App. 735, 195 Pac. 947.

Note that under the Practice Act (1851) \$393, interest commonly disqualified a husband to testify for his wife, even when the wife was not a party, if she was legally interested. Lisman v. Early (1859) $12 \mathrm{Cal}$. 282. When either spouse was a party, the other was absolutely incompetent. Practice Act (1851) §395; Dawley v. Ayers (1863) 23 Cal. 108. But when the husband's legal interest was adverse and separate from that of the wife, and the wife was not a party, the husband was competent even though his testimony inured to the legal benefit of the wife. Abrams v. Howard (1863) 23 Cal. 388. Here the wife was a sole trader. The husband's testimony in a separate action which was by stipulation to decide the wife's action was held admissible, where the husband's legal interest was adverse.

41 CAL. Code CIv. Proc. \$1881, subd. 1: "A husband cannot be examined for or against his wife without her consent; nor a wife for or against her husband, without his consent."

42 See Note (1914) 2 CaIIr. L. Rev. 148.

43 Falk v. Wittram (1898) 120 Cal. 479, 52 Pac. 707, 65 Am. St. Rep. 184. (wife's deposition excluded).

24 Cat. Pen. Code \$1332. See Notes (1914) 2 Catrf. L. Rev. 148; (1917) L. R. A. 1917E 1134. Literally, a witness-spouse could refuse to testify for as well as against the party-spouse. Likewise a waiver could not be imphed from the conduct of one spouse alone. 


\section{Waiver of the Privilege \\ a. Lack of proper objection}

Waiver is based on the consent of the party-spouse, express or implied. ${ }^{45}$ Failure on the part of the party-spouse present in court to object to the examination of the witness-spouse will constitute a waiver..$^{40}$ Likewise a general objection that the evidence is incompetent, irrelevant and immaterial is not ordinarily, if ever, sufficient to raise the question of competency. .77

A failure to object at a former trial for one offense is probably not a waiver for a subsequent trial on a different offense. ${ }^{48}$ But a third party may testify to what the wife said, and the same result is reached. ${ }^{40}$

b. Calling a spouse as a witness

Calling the witness-spouse on the behalf of the party-spouse constitutes a waiver of the privilege. ${ }^{50}$ Likewise cross-examination of the witness-spouse by the party-spouse before moving to strike out waives the privilege. ${ }^{51}$

Where a husband, joint defendant with his wife, bas been called by the plaintiff and has testified favorably to the wife, her privilege is waived. When the husband's counsel recalls him, and the wife fails to object, she again waives the privilege. ${ }^{52}$

45 People v. Singh (1920) 182 Cal. 457, 188 Pac. 987.

46 People v. Chadwick (1906) 4 Cal. App. 63, 87 Pac. 384 ; People v. Singh, sttpra note 45 .

47 People v. Singh, supra note 45.

Estate of Pusey (1919) 180 Cal. 368, 181 Pac. 648 held such objection insufficient where the party-spouse was contending that the witness was not then his wife, although the effect of the decision was to hold her his wife at all times. The court said that such a general objection might be sufficient under some circumstances, citing Humphrey v. Pope (1905) 1 Cal. App. 374, 82 Pac. 223. The latter case related solely to privileged communications, however, and was distinguished on that ground in People v. Singh, supra, holding a general objection insufficient.

48 People v. Chadwick (1906) 4 Cal. App. 63, 87 Pac. 384. In this case the wife's testimony against her husband at a forgery trial was held admissible against him on a later perjury trial, in the District Court of Appeal. The California Supreme Court on petition for transfer of the cause held the evidence admissible, since not objected to, and since admissible anyhow on the issue of the materiality of the husband's prior testimony.

40 See authorities cited supra note 32 .

50 Steinburg v. Meany (1879) 53 Cal. 425; Percival v. Jack (1906) 4 Cal. App. $199,90 \mathrm{Pac}$. 555 (the evidence was said to be a waiver, although a previous objection had been made and overruled).

51 Schwartz v. Brandon (1929) 97 Cal. App. 30, 275 Pac. 448 (husband and wife joint defendants). In People v. Anderson (1864) $26 \mathrm{Cal} .130$ cross-examination was said to be a waiver, although a previous objection had been made and overruled.

52 Schwartz v. Brandon, supra note 51.

On this subject in general see Note (1912) 40 L. R. A. (N. S.) 43. Note an erroneous reference in 4 WIGMORE, EvIDENCE (2d ed. 1923) $\$ 2242$, note 6 , to the California code as providing that a party taking the stand waives his privilege for his wife's testimony. 


\section{c. Other forms of waiver}

Where both husband and wife are joined, a disclaimer by the husband of any interest in the subject-matter of the action is said to waive the privilege. ${ }^{53}$

Where a creditor of one spouse brings an action against both husband and wife to set aside alleged fraudulent trausfers from one spouse to the other, placing the deed or agreement in issue will waive the privilege, at least as to the bona fides of the instrument. ${ }^{54}$

\section{Harmless Error}

A defendant in a criminal case is not injured by the bare testimony of a witness that she is his wife. ${ }^{55}$ Where a witness objected to as defend-

53 Johnston v. St. Sure (1921) 50 Cal. App. 735, 195 Pac. 947. But since the testimony can be neither for nor against the nommal party, this seems not a waiver but a case wliere the privilege is not applicable.

54 Tobias v. Adams (1927) 201 Cal. 689, 258 Pac. 588 (the recording and pleading in defense of a written agreement relinquishing the husband's rights in community property to the wife held a waiver of the privilege as to both defendant spouses); Schwartz v. Brandon (1929) 97 Cal. App. 30, 275 Pac. 488 (setting up the deed in the joint answer held a waiver).

Two earlier cases seem to be contrary. In First National Bank v. Ranger (1920) 49 Cal. App. 447, 193 Pac. 788 conveyances from husband to wife were alleged fraudulent both in law and in fact. The wife denied these allegations, but the husband was not allowed to testify over the wife's objection. Schwartz v. Brandon, supra, attempted to distinguish the case as one where the bona fides of the transaction were not placed in issue.

In Marple v. Jackson (1920) 184 Cal. 411, 193 Pac. 940, the wife sued to enjoin a sale, under execution issued against the husband, of land alleged to be her separate property. The defendant defended on two grounds: first, lack of delivery of the deed; second, fraudulent transfer. The wife pleaded the deed and rested. Her objection to the examination of the husband as to the delivery of the deed was sustained, and the California Supreme Court affirmed the ruling. The case seems indistinguishable unless the waiver extends solely to the bona fides of the transaction or instrument, since if pleading the deed waived the privilege, it would seen that the waiver should extend to all testimony by the husband as to all matters concerning the validity of the deed. The case cannot be distinguished on lack of reliance by creditors, for, although the original judginent was based on a tort claim arising after the conveyance, a fraudulent intent at the time the deed was executed would extend prima facie at least to subsquent creditors, and make the deed void as to them. See Horn v. Volcano Water Co. (1859) 13 Cal. 62, 73 An. Dec. 569; Banning v. Marleau (1901) 133 Cal. 485, 65 Pac. 964; Hemenway v. Thaxter (1907) $150 \mathrm{CaI} .737,90$ Pac. 116; 12 R. C. I. 496 . Since the court in Schwartz v. Brandon, supra, attempted to distinguish Marple v. Jackson, supra, the case may still be law on its facts.

Some doubt was thrown upon the privilege in fraudulent transfer cases by the decision in Gill v. White (C. C. A. 9th, 1918) 249 Fed. 59. The testimony of the wife of a bankrupt as to fraudulent transfers was ruled out by the referee under CaI. Code Crv. Proc. \$1881, and this was assigned as error. The District Court affirmed the ruling, but on a wholly different ground; the Circuit Court of Appeals merely affirmed upon the same gronnd as below.

55 On the California cases, see (1927) 1 So. Carrf. Rev. 96.

In People v. Jolmson (1908) 9 Cal. App. 233, 98 Pac. 682, the prosecuting witness was asked if she was the defendant's wife at the time of the assault. Upon her statement that she could not remember, no further questions were asked. 
ant's wife testified on cross-examination by the defendant that she was not his lawful wife, the error was held cured. ${ }^{56}$ Later testimony by a defendant to the same facts brought out in examination of the other spouse without the consent of the defendant will render the error harmless. ${ }^{57}$

\section{Inference from Exercise of the Privilege}

The testimony excluded by the exercise of the privilege is not to be presumed unfavorable to the party-spouse..$^{58}$

\section{Cessation of the Privilege}

The privilege ends with death in criminal cases, necessarily, since testimony cannot be for or against a spouse not a party.59 Probably the same rule applies in civil cases..$^{60}$ But a different rule applies to privileged communications, which are to be distinguished..$^{61}$

Divorce will likewise terminate the privilege. ${ }^{62}$

\section{Exceptions to the Privilege}

\section{In Civil Cases}

a. "A civil action or proceeding by one against the other."

56 People v. Anderson (1864) 26 Cal. 130 (under Practice Act (1851) 8395).

57 People v. Ketchum (1887) 73 Cal. 635, 15 Pac. 353; People v. Fultz (1895)

109 Cal. 258, 41 Pac. 1040.

58 Comment by the prosecuting attorney upon a defendant's failure to call his spouse as a witness is prejudicial misconduct. People v. Heacock (1909) $10 \mathrm{Cal}$. App. 450, 102 Pac. 543 (homicide); People v. Terramorse (1916) 30 Cal. App. 267, $157 \mathrm{Pac}$. 1134 (larceny). The weight of authority is in accord. 4 WIGMoRE, EvrDENCE (2d ed. 1923) \$2243; Note (1911) 34 L. R. A. (N. s.) 816.

59 Savings Union Bank \& Trust Co. v. Crowley (1917) 176 Cal. 543, 169 Pac. 67.

60 Savings Union Bank \& Trust Co. v. Crovley, supra note 59, may be distinguished as applying to privileged communications alone (though hardly a valid distinction on the question of the estate of a spouse as an equivalent party to a spouse) or may be restricted to actions where one spouse and the estate of the other spouse are adverse parties.

The great weight of authority holds that the privilege ends with death of a spouse. See 4 Wigmore, Evidence (2d ed. 1923) 82237; Note, Ann. Cas. 1917D 216. Where for the spouse, the common law incoinpetency ended with death. 1 WIGMORE, EvIDENCE (2d ed. 1923) §610.

61 Emmons v. Barton (1895) 109 Cal. 662, 42 Pac. 303, which concerned privileged communications, is erroneously cited for the proposition that the present privilege is not ended by death in 4 WIGMORE, EVIDENCE (2d ed. 1923) \$2237, and in Note, Ann. Cas. $1917 \mathrm{D} 216$.

62 People v. Loper (1910) 159 Cal. 6, 112 Pac. 270, Ann. Cas. 1912B 1193 (divorced wife can testify as intimate acquaimtance to mental condition of accused former husband) ; Estate of Pusey (1919) 180 Cal. 368, 181 Pac. 648. The weight of authority seems to be in accord. 4 WIGMORE, EvmENCE (2d ed. 1923) \$2237; 1 ibid. \$610; Notes, Ann. Cas. 1912B 1200; Ann. Cas. 1918E 193.

63 Car. Code Crv. Proc. \$1881, subd. 1. In Savings Union Bank \& Trust Co. v. Crowley (1917) 176 Cal. 543, 169 Pac. 67, an action by a wife against her husband's estate was held a civil action against the husband within the meaning of the statute, but the question was of privileged communications. 
The privilege has never been claimed in a divorce case in California, ${ }^{64}$ although parties have been allowed to testify without question. ${ }^{65}$ An action for divorce would seem to fall within the present exception. Although an action for divorce is an action in rem as regards the marital status, ${ }^{66}$ and the custody of minor children within the jurisdiction of the court, ${ }^{67}$ it is an action in personam as regards alimony and costs. ${ }^{68}$

Viewed as an action in rem, the marital status being the res, both husband and wife have an interest in that status, and the testimony will be for or against them as parties. Hence the action would seem to be one against the defendant spouse within the meaning of the statute.

An action for divorce is an equitable action ${ }^{69}$ to which the rules of evidence in civil cases are applicable, in general..$^{0}$ It has been said to be an action on contract, at least as to the filing of a cross-complaint under section 442 of the Code of Civil Procedure. ${ }^{71}$

64 In Mitchell v. Superior Court (1912) 163 Cal. 423, 125 Pac. 1061, a wife in proceedings ancillary to divorce made an affidavit of certain non-payment by the husband under court order, on which the husband was committed for contempt. The husband's claim of privilege in the contempt proceedings was refused on the ground that since the proceeding was one ancillary to divorce, it should be governed by the same rules as to competency of witnesses: i.e., that there was no privilege. The case is so cited in Marple v. Jackson (1920) 184 Cal. 411, 414, 193 Pac. $940,941$.

65 An inference that the parties are competent is contained in CAL. CIV. Code \$130: "No divorce can be granted ... . upon the uncorroborated statement, admission, or testimony of the parties ...." This would not necessarily negative the existence of a privilege however, since a waiver wonld be possible.

Some forty cases in which at least one party testified are collected in: 3 KERR's CaI. Dig. 1915, 3081, 3099-3101; CaI. Dig. 1915-1919 Supp. 613-14; CaI. Dig. 19201923 Supp. 507-8; CaL. Dig. 1924-1927 Supp. 64; CaI. Current Dig. 1928, 220; Cat. Current Dig. 1929, 219-20.

At common law, no exception in divorce cases was recognized. But many cases construed statutes making parties competent as allowing the testimony of husband and wife in a divorce action. 4 WIGMORE, EVIDENCE (2d ed. 1923) $\$ 2239 ; 9$ R. C. I. 434. 247.

68 Estate of Lee (1927) 200 Cal. 310, 253 Pac. 145; 9 CAL. JUR. 629; 9 R. C. L.

67 Newman's Estate (1888) 75 Cal. 213, 16 Pac. 887, 7 Am. St. Rep. 146.

68 De la Montanya v. De la Montanya (1896) 112 Cal. 101, 44 Pac. 345, 53 Am. St. Rep. 165, 32 L. R. A. 82 ; Matter of McMullin (1913) 164 Cal. 504, 129 Pac. 773; Shillock v. Shillock (1914) 24 Cal. App. 191, 140 Pac. 954.

60 Lyons v. Lyons (1861) 18 Cal. 448; Wadsworth v. Wadsworth (1889) $81 \mathrm{Cal}$. 182, 22 Pac. 648, 15 Am. St. Rep. 38; Gaston v. Gaston (1896) 114 Cal. 542, 46 Pac. 609, 55 Am. St. Rep. 86.

709 CaL. JUR. 731. An additional indication is found in Van Horn v. Van Horn (1907) 5 Cal. App. 719, 91 Pac. 260, applying to a divorce action Cat. Code CTv. Proc. \$2053, relating to evidence of character of a party "in a civil action."

71 Wadsworth v. Wadsworth (1889) 81 Cal. 182, 22 Pac. 648, 15 Am. St. Rep. 38 ; Mott v. Mott (1889) 82 Cal. 413, 22 Pac. 1140. 
The state has an interest in the action for divorce, ${ }^{72}$ but the attorneys in the case represent the respective parties, and the court in a sense represents the state. ${ }^{73}$

It would seem clear then, especially in view of the strict construction of the privilege, that an action for divorce should be held a civil action or proceeding by one spouse against the other, ${ }^{74}$ and hence within the present exception..$^{75}$

b. "An action brought by husband or wife against another person for the alienation of the affections of either husband or wife." $" 76$

c. "An action for damages against another person for adultery committed by either husband or wife."

d. "When the executor and proponent of a will is made the defendant in a contest thereof, he and his wife, she being the sole beneficiary under the will, may not refuse to testify, because of the relation of husband and wife." 78

\section{In Criminal Cases}

a. An exception to the privilege is made in case of "a criminal action or proceeding for a crime committed by one against the other"70 or "criminal actions or proceedings for a crime committed by one against the person or property of the other"so or "criminal violence upon one by the other." $" 81$

72 Deyoe v. Superior Court (1903) 140 Cal. 476, 74 Pac. 28, 98 Am. St. Rep. 73 ; Rehfuss v. Rehfuss (1915) 169 Cal. 86, 145 Pac. 1020. See Note (1837) 30 Am. Dec. 544.

73 Rehfuss v. Rehfuss, supra note 72.

74 The only proper parties to a divorce action are, generally, the husband and wife. Cummings v. Cummings (1888) 75 Cal. 434, 17 Pac. 442; Weyer v. Weyer (1919) 40 Cal. App. 765, 182 Pac. 776.

75 See Notes (1893) 34 Am. St. Rep. 482; (1911) 25 L. R. A. (N. s.) 45; Ann. Cas. 1913B 3.

Before tbe code, under Cal. Stats. 1870, c. 188, husband and wife were expressly made competent witnesses in divorce actions. See Evans v. Evans (1871) $41 \mathrm{Cal}$. 103.

76 Car. Code Civ. Proc. $\$ 1881$, subd. 1, amended by Cal. Stats. 1907, c. 68; Pratt v. Harrold (1920) 47 Cal. App. 166, 190 Pac. 372.

77 Cat. Code Crv. Proc. \$1881, as amended by Cal. Stats. 1907, c. 68.

78 Estate of Goff (1897) 5 Coffey's Prob. Dec. 432. 'This early exception by decision has been neither followed nor disapproved.

79 Cal. Code Ctv. Proc. \$1881, subd. 1.

80 CAL. Pen. Code $\$ 1322$.

81 CAI. PEN. CODE \$1322. Voluntary intercourse with a girl under the age of consent is not an act of criminal violence. People v. Curiale (1902) 137 Cal. 534, 70 Pac. 468, 59 L. R. A. 588. But criminal violence is no longer important in view of the blanket provision in the code. In re Kantrowitz (1914) 24 Cal. App. 203, 140 Pac. 1078 (rape of wife after marriage to defendant co-principal); People v. Rader (1914) 24 Cal. App. 477, 141 Pac. 958 (assault on wife). See Note, L. R. A. 1917E 1133. 
A proceeding for contempt, ancillary to divorce proceedings, was granted not to fall within the exception, if a criminal proceeding; but was held there of the same nature as the divorce action. ${ }^{82}$

It has been uniformly held that the present exception does not extend to acts committed before the marriage, ${ }^{83}$ although the marriage is after arrest but before trial, ${ }^{84}$ or although an annulment has been secured but is not yet final. ${ }^{85}$

b. "Cases of criminal actions or proceedings for bigamy or adultery." c. "Cases of criminal actions or proceedings brought under the provisions of sections two hundred and seventy and two hundred and seventy a of this code." 87 Sections 270 and 270 a relate respectively to the failure of a father to provide his child with necessaries, and to the failure of a husband to support his wife. Section 270e of the Penal Code is express on the absence of any privilege. ${ }^{88}$

d. A prosecution for the crime of placing or permitting the placing of one's wife in a house of prostitution. ${ }^{89}$

e. A prosecution of the husband for the crime of pimping.90 The wife is competent whether she married the defendant before or after the offense was committed. ${ }^{91}$

82 Mitchell v. Superior Court (1912) $163 \mathrm{Cal}$. 423, $125 \mathrm{Pac}$. 1061. See Note (1913) 41 L. R. A. (N. S.) 1214.

88 People v. Curiale (1902) 137 Cal. 534, 70 Pac. 468, 59 L. R. A. 588 (statutory rape) ; People v. Johnson (1908) 9 Cal. App. 233, 98 Pac. 682 (prosecution for assault on alleged wife); In re Kantrowitz (1914) 24 Cal. App. 203, 140 Pac. 1078.

The cases are almost uniformly in accord: Notes (1903) 67 L. R. A. 499; (1906) 2 L. R. A. (N. S.) 862 ; (1909) 22 L. R. A. (N.'s.) 240; (1913) 45 L. R. A. (N. s.) 396. But see 4 WIGMORE, EvIDENCE (2d ed. 1923) \$2239, note 9: "To hold that the offense when committed, was not done to the wife, so as to be a 'crime against the other', is to misread the statute. The woman's consent to marriage cannot remove the crime, however much it may discredit her testimony."

For contrary rule for pimping, see infra note 90. For "crime directed against spouse but taking effect against a third person" as within the exception, see Note (1924) 35 A. L. R. 1132.

84 People v. Souleotes (1915) 26 Cal. App. 309, 146 Pac. 903 (statutory rape).

85 People v. Livingston (1928) 88 Cal. App. 713, 263 Pac. 1036 (statutory rape).

86 Car. Pen. Code \$1322. See Note (1923) 35 A. L. R. 138.

87 CAL. Pen. Code $\$ 1322$.

88 People v. Martin (1929) 100 Cal. App. 435, 280 Pac. 151 (abandoning wife).

89 Cat. Pen. Code \$266g; People v. Duncan (1913) 22 Cal. App. 430, 134 Pac. 797; People v. Barrett (1929) 207 Cal. 47, 276 Pac. 1003.

90 Cal. Stats. 1911, c. 15; People v. Barrett, supra note 89.

People v. Edwards (1915) 28 Cal. App. 716, 153 Pac. 975 held the statute not impliedly repealed by subsequent anendments to CAX. PEN. CODE $\$ 1322$ in Cal. Stats. 1911, c. 103.

91 Cal. Stats. 1911, c. 15. 


\section{B. Privileged Communications}

\section{In General ${ }^{22}$}

The code provides that neither husband nor wife can "during the marriage or afterward, be, without the consent of the other, examined as to any communication made by one to the other during the marriage."103

The privilege is to be strictly construed, since its tendency is to prevent the full disclosure of the truth. ${ }^{04}$

The privilege applies in criminal as well as in civil actions. ${ }^{05}$

\section{The Scope of the Privilege}

\section{Any Communication}

The privilege applies to "any comnunication made by one to the other during the marriage." made in confidence. ${ }^{.7}$

A communication by one spouse to a third person is clearly not within the privilege. ${ }^{98}$ A divorce complaint has been held not to be a privileged communication.99

92 See Note (1890) 29 Am. St. Rep. 411.

93 Cax. Code Cry. Proc. \$1881, subd. 1.

94 Lloyd v. Pennie (D. C. N. D. Cal. 1892) 50 Fed. 4 (construing Car. Code Crv. PRoc. §1881, subd. 1) ; People v. Loper (1910) 159 Cal. 6, 112 Pac. 720, Ann. Cas. 1912B 1193.

05 People v. Mullings (1890) 83 Cal. 138, 23 Pac. 229, 17 Am. St. Rep. 233; People v. Warner (1897) 117 Cal. 637, 49 Pac. 841.

96 CAT. Code CIV. PRoc. \$1881, subd. 1.

07 'No Court can positively determine what conversation husband and wife at the time intended as referring to their marital relations; therefore the Legislature has positively prohibited all communications." Estate of Low (1877) Myr. Prob. $143,144$.

"The privilege at common law did not extend to communications which were not in their nature confidential; and although such communications were generally held to be confidential, yet some very difficult questions did occasionally arise as to the character of the communications; but our code sweeps away that embarrassing distinction by extending the privilege to any communication made by one to the other during the marriage." "People v. Mullings (1890) 83 Cal. 138, 140, 23 Pac. 229, 230, 17 Am. St. Rep. 223, 224.

Dean Wigmore criticizes this construction of the statute: "In many jurisdictions this fundamental element of confidence is not expressly named in the statutory enactunent; it privileges "any communication." Soine courts, however, bave construed this phrase into the spirit of the correct principle, and have inplied a limitation to confidential communications.... No justification for such an extension of the privilege has ever been attempted, and it must be supposed that this broad statutory phrasing originated in inadvertence. It is proper enough to maintain (as already noticed) that all marital communications should be presumed to be confidential until the contrary appears; but if the contrary appears, there is no reason for recognizing the privilege." 5 WIGMORE, Evmence (2d ed. 1923) \$2336.

08 First National Bank v. De Moulin (1922) 56 Cal. App. 313, 205 Pac. 92 (letter from husband of defendant to the plaintiff held admissible).

90 Johns v. Baender (1919) 40 Cal. App. 790, 182 Pac. 55. 
2. Communications, not Acts

The fact of communication, as distinguished from the communication itself, is not privileged.100

Communications, not acts, are included within the privilege..$^{101}$ The delivery of a deed is not a privileged communication, ${ }^{102}$ nor is mental condition. ${ }^{103}$ Testimony as to the giving of money by one spouse to the other has been held not privileged. ${ }^{104}$

\section{Communications as to Business Relationship}

One spouse may be permitted to testify to communications made by the other spouse concerming business matters, between the two, at least in an action between one spouse and the estate of the other. ${ }^{105}$

The rule may be extended to cover business communications between husband and wife, however brought in question. ${ }^{106}$

100 Estate of Pusey (1919) $180 \mathrm{Cal} .368,181$ Pac. 648 (fact of communication by husband to wife admitted to show the husband's knowledge of the wife's whereabouts).

1015 Wrgarore, Evmence (2d ed. 1923) §2337.

102 Poulson v. Stanley (1898) 122 Cal. 655, 55 Pac. 605, 68 Am. St. Rep. 73.

103 People v. Loper (1910) 159 Cal. 6, 112 Pac. 720, Ann. Cas. 1912B 1193; People v. Mackey (1922) 58 Cal. App. 123, 208 Pac. 135; Note, Ann. Cas. 1912B 1200.

104 Tobias v. Adams (1927) 201 Cal. 689, 258 Pac. 588 (but this may be upheld on the alternative ground of business communications).

105 "The protection of the right to contract with each other respecting their separate property requires that each should be allowed to testify concerning such contracts, in case of an action between them thereon." Savings Union Bank \& Trust Co. v. Crowley (1917) 176 Cal. 543, 547, 169 Pac. 67, 69. The action was by the husband's estate against the wife who claimed certain property of the husband's as pledgee. Since it was held an action by one spouse against the other, the privilege would not apply anyhow.

An early dictum that business communications are privileged is found in Estate of Low (1877) Myr. Prob. 143.

${ }^{106}$ In Tobias v. Adams (1927) 201 Cal. 689, 258 Pac. 288, the action was by creditors against husband and wife, to set aside alleged fraudulent trausfers from husband to wife. Testimony by the wife as to the husband's giving her the money to purchase this property was held improperly excluded. The court cited Poulson v. Stanley (1898) 122 Cal. 655, 55 Pac. 605, 68 Am. St. Rep. 73, holding delivery of a deed not a communication, and Savings Union Bank \& Trust Co. v. Crowley, supra note 105, thus partly at least relying on the business communications exception.

Earher decisions are equivocal. In McIntosh v. Hunt (1916) 29 Cal. App. 779,157 Pac. 839, the husband was defendant in an action to establish a trust in property conveyed to the husband by the wife before her death. Conversations between husband and wife at the time of the execution of the deeds were excluded, but the California Supreme Court, in denying a petition for a rehearing, was not prepared to give its assent to the exclusion of the evidence. No ground was stated. In Emmons v. Barton (1895) 109 Cal. 662, 42 Pac. 303, similar conversations were excluded. The case is distinguished in Savings Union Bank \& Trust Co. v. Crowley, as not relating to a contract between husband and wife. But see Note (1890) 29 Am. St. Rep. 420. 


\section{Source of the Testimony ${ }^{107}$}

Communications between husband and wife may be testified to by any third person, ${ }^{108}$ whether he gains his knowledge by presence at the time of the communications ${ }^{109}$ or from one of the spouses later, ${ }^{110}$ and though the means of obtaining the information be illegal..$^{111}$

Whether the known presence of a third person removes the privilege, so that the spouse himself may testify as to the communication, has not been directly decided. The language of the code would probably lead to an enforcement of the privilege. ${ }^{112}$

107 See in general Note (1911) 33 L. R. A. (N. s.) 477.

108 Lloyd v. Pennie (D. C. N. D. Cal. 1892) 50 Fed. 4, construed CAc. Code Civ. Proc. \$1881, subd. 1. Letters from husband to wife found in possession of the wife's administrator after the death of both spouses were held adinissible. "Such communications are received in evidence when produced by parties who do not occupy the confidential relation." (50 Fed. at 10.) The court disapproved the dictum in People v. Mullings (1890) 83 Cal. 138, 23 Pac. 229, 17 Am. St. Rep. 223 to the effect that "the privilege applies to the communication."

In People v. Swaile (1909) 12 Cal. App. 192, 107 Pac. 134, a letter from husband to wife given by the wife to an officer was held admissible. . . "There was no examination of the wife as to a privileged communication. ..." (12 Cal. App. at 196, 107 Pac, at 137.) In People v. Mitchell (1923) 61 Cal. App. 569, 215 Pac. 117 a letter from husband to wife found in a house vacated by the wife was held admissible. The court confused the present privilege with that as to anti-marital testimony, but reached a correct result. See 5 WIGMore, Evmence (2d ed. 1923) $\$ 2339$.

In People v. Baender (1924) 68 Cal. App. 49, 228 Pac. 536 the wife's attorney was allowed to testify concerning a letter from the husband to the wife. See Notes (1906) 3 Ann. Cas. 915; Ann. Cas. 1912B 1001; (1928) 37 YaLE L. J. 669.

109 People v. Murphy (1872) $45 \mathrm{Cal}$. 137; Hayden v. Collins (1905) $1 \mathrm{Cal}$. App. 259, 81 Pac. 1120 (excluded conversation of husband and wife with guardian of the plaintiff as immaterial. The citation under privileged communications in 9 KERR's CAL. DIG. 1915, 9672, seems erroneous); Lauricella v. Lauricella (1911) 161 Cal. 61, 118 Pac. 430 (allowed as admission against communicating spouse); People v. Colombo (1924) $70 \mathrm{Cal}$. App. 489, 233 Pac. 413 (allowed wife's warning to husband, overheard by officer, for purpose of showing husband's reaction); People v. Morliar (1926) $78 \mathrm{Cal}$. App. 380, $248 \mathrm{Pac}$. 975 (officers present allowed to testify to conversation between husband and wife). See Note (1911) 9 MICH. L. REv. 248.

110 People v. Swaile (1909) 12 Cal. App. 192, 107 Pac. 134; People v. Baender (1924) $68 \mathrm{Cal}$. App. 49, $228 \mathrm{Pac}$. 536. These cases seem incorrect on principle, since the spouse was the source of the information. 5 Wromore, EvDENCE (2d ed. 1923) \$2339.

People v. Smith (1926) 78 Cal. App. 68, 248 Pac. 261 contained a weak dictum to the contrary, but the court confused the present privilege with that as to anti-marital testimony.

111 People v. Swaile, supra note 110. See Note (1911) 34 L. R. A. (N. s.) 58, 65.

112 Under CAI. CoDE CIv. Proc. \$1881, subd. 1, any communication is privileged whether confidential or not, consequently the fact that confidence is negatived by the known presence of a third person seems immaterial. The weight of authority of course refuses the privilege where confidence is negatived. See 28 R. C. L. 528 . 


\section{Exercise of the Privilege}

1. Who May Claim the Privilege

Neither spouse may be forced to testify without the consent of the other. ${ }^{113}$ It has been held that the creditors of a deceased spouse cannot waive the privilege. ${ }^{114}$

2. Waiver

a. Lack of proper objection

Failure to object at the time of introduction of the evidence waives the privilege. ${ }^{115}$ A general objection that the evidence (of communications) is incompetent is probably sufficient in California courts, ${ }^{116}$ but the federal courts sitting in California require a specific objection. ${ }^{117}$

b. Other forms of waiver

The privilege is not waived by a defendant-spouse's taking the stand to testify. 118

In a suit by creditors to set aside alleged fraudulent transfers, the recording and pleading of a written agreement relinquishing to the wife the husband's rights in the commumity property will constitute a waiver of the privilege. ${ }^{119}$

Cross-examination of the witness-spouse after a proper objection has been overruled will not waive the privilege. ${ }^{120}$

\section{Harmless Error}

The erroneous admission of testimony as to privileged conımunica-

113 'No disclosure can be forced from either spouse without the consent of the one against whom it is sought to be used." People v. Mullings (1890) 83 Cal. $138,141,23$ Pac. 229, 230, 17 Am. St. Rep. 223, 225. On principle, the privilege belongs to the commumicating spouse. 5 WIGMORE, EvDENCE (2d ed. 1923) \$2340; Note (1914) 2 Cariz. L. REv. 148.

114 Emmons v. Barton (1895) 109 Cal. 662, 42 Pac. 303.

115 Johns v. Baender (1919) 40 Cal. App. 790, 182 Pac. 55.

116 In People v. Mullings (1890) 83 Cal. 138, 23 Pac. 229, 17 Am. St. Rep. 223 , the first objection was specifically on the ground of privileged communications. General objections made to similar questions subsequently asked the same witness were held to be sufficient. People v. Mullings was cited in Humphrey v. Pope (1905) $1 \mathrm{Cal}$. App. 347, 82 Pac. 223 to sustain the holding that a general objection, although the only one offered, is sufficient. The court likewise cited People v. Warner (1897) 117 Cal. 637, 49 Pac. 841, where a specific objection was recognized as actually made at the trial. A rule in terms limiting Humphrey v. Pope was laid down in Estate of Pusey (1919) 180 Cal. 368, 181 Pac. 648, but the privilege as to anti-marital testimony was there concerned.

117 Proffitt v. United States (C. C. A. 9th, 1920) 264 Fed. 299.

118 People v. Mullings (1890) 83 Cal. 138, 23 Pac. 229, 17 Am. St. Rep. 223; People v. Warner (1897) 117 Cal. 637, 49 Pac. 841.

119 Tobias v. Adams (1927) 201 Cal. 689, 258 Pac. 588.

120 Jameson v. Tully (1918) 178 Cal. 380 , 173 Pac. 577 . For waiver by calling one spouse as a witness for the other, see Note (1912) 40 L. R. A. (N. s.) 43. 
tions is cured by striking out the evidence and instructing the jury to disregard the questions and answers. ${ }^{121}$

\section{Cessation of the Privilege}

1. Death

Clearly by the language of the code $\mathrm{e}^{\mathbf{1 2 2}}$ the death of either spouse will not end the privilege. ${ }^{123}$ The death of both spouses ends the privilege, since the testimony is then necessarily given by a third person..$^{124}$

2. Separation

Whether communications made between husband and wife living in separation are privileged has not been determined in California. ${ }^{125}$

3. Divorce

Divorce will not terminate the privilege as to conmmunications made during their marriage. ${ }^{126}$

\section{Exceptions to the Privilege}

1. "A civil action or proceeding by one against the other."127

2. "A criminal action or proceeding for a crime committed by one against the other."128

3. "An action brought by husband or wife against another person for the alienation of the affections of either husband or wife."120

121 People v. Smith (1926) 78 Cal. App. 68, 248 Pac. 261.

122 Car. Code Crv. Proc. \$1881, subd. 1.

123 Estate of Low (1877) Myr. Prob. 143; Emmons v. Barton (1895) 109 Cal. 662, 42 Pac. 303; Nicoll v. Nicoll (1913) 22 Cal. App. 268, 133 Pac. 1144; Kershaw v. Madsen (1923) 62 Cal. App. 11, 216 Pac. 55.

124 See cases cited supra note 108.

125 In People v. Baender (1924) 68 Cal. App. 49, 228 Pac. 536, a letter written by the husband to the wife after an interlocutory decree of divorce had been rendered was admitted, but on the ground that it was offered by, and in connection with, the testimony of a third person.

The weight of authority holds such communications not privileged on two grounds: first, they are not within the policy' of the privilege, the relation is not one to be fostered (5 WIGMORE, EVIDENCE (2d ed. 1923) \$2341); second, they are not made in confidence. See 28 R. C. L. 526; Note, L. R. A. 1916 B 1275. Since confidence is not a requisite in California the privilege may be applied in this situation.

126 People v. Mullings (1890) 83 Cal. 138, 23 Pac. 229, 17 Am. St. Rep. 223 ; see Estate of Pusey (1919) 180 Cal. 368, 373, 181 Pac. 648, 650.

127 CAI. CODE Crv. Proc. \$1881, subd. 1. For a discussion of divorce, see note 65. For an action by the estate of a spouse against the other spouse, see supra notes 63, 105.

128 CaI. Code Civ. Proc. \$1881, subd. 1.

129 Cat. Code Crv. Proc. $\$ 1881$, subd. 1, as amended by Cal. Stats. 1907, c. 68; Jameson v. Tully (1918) $178 \mathrm{Cal} .380,173 \mathrm{Pac}$. 577 (letters from wife to husband admissible against the defendant in an action by the husband). Contra: Humphrey v. Pope (1905) 1 Cal. App. 374, 82 Pac. 223 (before the amendment). See Notes (1918) 4 A. L. R. 497; (1924) 36 A. L. R. 1068. 
4. "An action for damages against another person for adultery committed by either husband or wife." 1130

5. In prosecutions for the crime of placing or permitting the placing of one's wife in a house of prostitution "a wife is a competent witness against her husband."131 This exception has been applied to communications by the husband to the wife. ${ }^{132}$

6. In prosecutions for failure of a father to provide his child with necessaries ${ }^{133}$ or for failure of a husband to support his wife ${ }^{134}$ there is no privilege as to communications. ${ }^{135}$

7. In prosecutions for pimping, the defendant husband has no privilege "as to any transactions or as to any conversations."

III. THE POLICY OF THE PRIVILEGES

\section{A. Code Statement of the Policy}

"There are particular relations in which it is the pohicy of the law to encourage confidence and to preserve it inviolate; therefore, a person cannot be examined as a witness in the following cases: ..."137

\section{B. The Privilege as to Testimony For a Spouse}

That one spouse may not testify for the other without the consent of the other seems a legislative anachronism resulting from the unreasoning adoption of the language of the old common law disqualification..$^{138}$ Marital bias seems to have been a principal basis for the common law rule. ${ }^{139}$ As soon as incompetency is changed to privilege, its foundation becomes some policy of favoring or protecting the spouse and the marriage relationship, and not a distrust of the reliability of the testimony. How a privilege for testiniony favorable to a spouse could so protect the spouse is at best difficult to comprehend. In most cases the privilege will naturally be waived. But if the "marital bias" of the witness-spouse should for some reason have been reversed, and the witness-spouse refuse to testify for the other spouse (possible in criminal cases ouly) ${ }^{140}$ then domestic peace would seem to have suffered an upheaval (if only an additional one) by the very agency purporting to protect it.

130 Cal. Code Civ. Proc. \$1881, subd. 1.

131 Cat. Pen. Code \$266g.

132 People v. Duncan (1913) 22 Cal. App. 430, 134 Pac. 797 (husband's letters admitted without question).

133 Cal. Pen. Code \$270.

134 Ibid. \$2\%0a.

135 Ibid. \$270e; People v. Martin (1929) 100 Cal. App. 435, 280 Pac. 151.

130 Cal. Stats., 1911, c. 15.

137 Cal. Code Civ. Proc. \$1881.

138 Note (1914) 2 CALIF. L. REv. 148.

139 I WiGMTORE, EvIDENCE (2d ed. 1923) §601.

140 Cat. Pen. Code $\$ 1322$. 
The cases, or lack of them, illustrate forcibly the futility of the privilege. Since calling a witness-spouse for a party-spouse necessarily involves a waiver of the privilege, it is not remarkable that but one case has arisen directly involving this privilege. Where a husband, insane, brought suit by his guardian, a deposition by the wife in favor of the husband was excluded, since the husband was incapable of giving consent..$^{141}$ Such perverse application of a supposed "privilege" furnishes in itself sufficient argument for abolition.

\section{The Privilege as to Testimony Against a Spouse}

The principal reasons advanced in support of the privilege are: ${ }^{142}$ first, the danger of "disturbing the peace of families"; second, the "natural repugnance" of compelling one spouse to be the means of the other's condemnation. The conclusive refutation of these arguments receives a classical exposition in Dean Wigmore's treatise. ${ }^{143}$ As to the first, it is not followed logically; it could be at best a minor cause of dissension; and the peace protected is that of a wrongdoer. ${ }^{144}$ As to the second, it is a mere sentiment and unworthy to block the law's search for truth. Likewise it exemplifies the "sport" idea of litigation, which the law cannot afford to recogmize.

The policy expressed in the code ${ }^{145}$ furnishes no support for the privilege. The preservation of confidences would apply strictly to communications alone, an independent privilege. ${ }^{146}$

It is significant, as will be noted later, that the text-writers of the last century with but few exceptions, accepted and echoed the orthodox views as to this incompetency or privilege of husband and wife, ${ }^{147}$ while a few writers in legal periodicals early showed more liberal and progressive tendencies. ${ }^{148}$ The modern writers are nearly unanimous in their condemnation of the privilege. ${ }^{149}$

141 Falk v. Wittram (1898) 120 Cal. 479, 52 Pac. 707, 65 Am. St. Rep. 184.

1424 WIGMORE, EVIDENCE (2d ed. 1923) \$2228.

143 Ibid.

144 See also Bentham, Treatise on Judicial Evidence (Dumont, 1825) Bk. VII, 226; Bk. X, 238.

145 Car. Code CIv. Proc. §1881.

146 Note (1926) 26 CoL. L. REv. 897.

147 Best, Evidence (8th ed. 1893) 159, 535, 539; 2 Eurtotr, Evmence (1904) \$732; 1 Greenleaf, Evidence (16th ed. 1899) §254; 1 Phillips, Evidence (5th Amer. ed. 1868) 62-78; Reynolds, Evidence (3d ed. 1897) 132; Starkxe, Evmence (10th Amer. ed. 1876) 38; Stewart, HusbaNd aNd WIFE (1887) §56; Tyler, INFANCX AND COVERTURE (2d ed. 1882) 323; WHARTON, EVIDENCE (3d ed. 1888) \$427.

But for a more liberal view, yet approving CaL. Code CIv. Proc. \$1881, see RICE, EVIDENCE (1892) 525-32.

148 See Notes (1870) 1 AlbaNy L. J. 245 ; (1891) 35 Jour. JUR. 344; (1889) 53 Just. P. 19; (1860) 34 LaW T. 177; (1884) 78 LAW. T. 57; (1887) 82 LaW T. 355 ; (1896) 101 LAW T. 30.

But for a conservative view, see (1882) 3 CRIM. L. MAG. 155; (1852) 44 LEG. OBS. 57.

149 "This privilege las no longer any good reason for retention. In an age 
In practice the rule has been found an undesirable one. Successive exceptions to the privilege have been made by the legislature as new difficulties arose, until the rule has been riddled with complexity. Likewise the courts, mayhap while praising the rule, have gone out of their way to escape its logical conclusions. Thus declarations of one spouse to a third person may be shown, although they are a sort of testimony..$^{150}$

The doctrine of waiver has been extended to abolish the privilege for practical purposes in actions by creditors alleging fraudulent transfers of property between husband and wife. Setting up the conveyance or agreement in question is held a waiver, yet the instrument is obviously a necessary piece of evidence in defeating such a claim by creditors. ${ }^{151}$ The necessity for such a step is set out by Preston, J: ${ }^{152}$ "It would be monstrous if husband and wife might between themselves conspire to defraud the creditors of the one or the other and to conceal their act produce a written instrument which is immune from all inquiries and which must be accepted by the defrauded party as final. The freedoin of contract between husband and wife and the power to transmute community property into separate property or vice versa by agreenent between themselves renders it imperative that when sucli an agreeinent is relied upon by their joint answer, thereby the whole subject matter of said agreement is open to inquiry which may include communications from one to the other."

But is it not "monstrous" that husband and wife might in any case "conspire between theniselves" to suppress relevant evidence concerning the legal rights of a third person, or more vital still, concerning the interests of the state itself? Courts have recognized this, yet have been constrained to follow the requirements of the statute. The following quotation ${ }^{153}$ has been favorably cited by the Califorma Supreme Court on two occasions:" ${ }^{154}$ "On the whole the prevailing tendency of late years in both England and America is to regard the domestic confidence or the

which has so far rationalized, depolarized, and de-chivalrized the marital relation and the spirit of Femininity as to be willing to enact complete legal political equality and independence of man and woman, this marital privilege is the merest anachronism, in legal theory, and an indefensible ohstruction to truth, in practice." 4 WrGirore, Evidence (2d ed. 1923) \$2228. See also Jones, Evidence (3d ed. 1924) \$747; McKelvey, Evidence (3d ed. 1924) 423, note 19; Notes (1914) 2 Calif. L. Rev. 148; (1928) 13 Iowa L. Rev. 481; (1927) 31 Law Notes 108.

1004 WIGMORE, EVIDENCE (2d ed. 1923) §2332.

151 See supra note 54.

152 Tohias v. Adams (1927) 201 Cal. 689, 699, 258 Pac. 588, 592. This language is quoted with approval in Schwartz v. Brandon (1929) 97 Cal. App. 30, 275 Pac. 448.

153 SCHOULER, HUSBand ANd WIFE (1882) \$85.

104 People v. Langtree (1883) 64 Cal. 256, 259, 30 Pac. 813, 814; Marple v. Jackson (1920) 184 Cal. 411, 414, 193 Pac. 940, 941. 
ties of a spouse as of little consequence compared with the public convenience of extending the means of ascertaining the truth in all cases. ..."

One line of cases would seem at first blush an extension of the privilege. The exception made by the code for a crine by one spouse against the other has not been applied to criminal acts committed before the marriage, ${ }^{155}$ althougl policy and legal principle would lead to a contrary construction. ${ }^{156}$ But the crime in practically all $\operatorname{cases}^{157}$ has been statutory rape committed with actual consent. The true basis of the rule developed seems not to be favor of the marital privilege, but a feeling that such a crime (not a heinous one by the notoriously lax legal principles of morality) has been in some way wiped out by the later marriage. This is shown in the opinion of Cooper, $\mathrm{C}$., in a leading case: ${ }^{158}$

"Our legislature has seen fit to make the act of sexual intercourse with a female under the age of sixteen rape, regardless of the question of consent. The female may be a voluptous, abandoned woman, and may even solicit the male, but under the statute the party so solicited must resist at his peril. Even then, though he resist like Joseph of old, Potiphar's wife may cry out against him and hold up lis garment as evidence....

"It is claimed that the rule here adopted will prevent such crimes from being punished. We must construe the law, and not attempt to make it. But it is not apparent to us that it would be any great injustice to forbid the woman who marries a man freely, and lives with him as his wife, from testifying that he had sexual intercourse with her before she was sixteen years old and prior to her marriage."

The present privilege, then, is universally condemned by modern legal theorists. It is harmful in practice in that it works injustice by the suppression of evidence and in seeking to prevent greater injustice creates anomalies in the law. The administration of justice would be made speedier, the search for truth more complete in its results, and the ultimate decision reached more nearly just if the privilege were banished from the law of evidence.

\section{Privileged Communications}

Approval of the privilege as to confidential comnunications has been

155 Supra note 83.

156 "Again, as the innocent unmarried are not deemed to deserve the benefit of the rule, so too, conversely, its benefits are gained by the ingenious wrongdoer who brings himself within its formal terms by marrying the witness after service of subpoena and thus creating 'ad hoc' a domestic peace which is to be jealously safeguarded." 4 Wigarore, Evmence (2d ed. 1923) \$2230. See also Bentham, Treatise ON Judiciad Evidence (Dumont, 1825) Bk. VII, 238.

157 See supra notes $64,65,66$.

158 People v. Curiale (1902) 137 Cal. 534, 538, 70 Pac. 468, 470, 59 L. R. A. 588, 590. 
nearly universal. 159 The common law rule as to incompetency received just such an unhesitating commendation in the last century, especially by the text-writers. ${ }^{160}$ Recently a current of question and challenge of the present privilege has made itself felt, and it would seem that the slow process of reason against the inherited dogma of the law is again beginning the course of its triumphal evolution. ${ }^{161}$

At the risk of being "the inquisitive little Peterkin at the bar, questioning too rashly the postulated platitudes of the Caspars in the profession," $" 162$ we will examine the reasons put forward in support of the privilege, and attempt to demonstrate their insufficiency. ${ }^{163}$

Dean Wigmore states the policy briefly: ${ }^{164}$

"The communications originate in confidence; the confidence is essential to the relation; the relation is a proper object of encouragement by the law; and the injury that would inure to it by disclosure is probably greater than the benefit that would result in the judicial investigation of truth."

First, "the confidence is essential to the relation." This fundamental proposition has been doubted by some writers. "The fact that married women are far less dependent than formerly, upon the caprice of their husbands in respect to their control of person, property, and children, may, at least to some extent, remove the objection to the disclosure even of communications made during the marriage."165

"By the modern enlargement of the wife's separate contract and property relations, moreover, the spouses are presented, not so constantly as partakers of one another's confidence, but rather as persons having adverse interests to maintain, or else as principal and agent."106 If the "modern" enlargement of the wife's rights led to this conclusion in 1882, how much stronger must that conclusion be today!

These cominunications between husband and wife are usually spoken of as "sacred," "hallowed" or "confided to the bosom of the wife."167 But

159 See authorities cited supra note 147 and Notes (1914) 2 CALIF. L. REv. 148; (1911) 9 MTCH. L. Rev. 248; (1928) 37 YaIE L. J. 669.

160 See supra note 147 .

161 Speaking of the present privilege: "But there is still a survival of the old idea in the exception as to private and confidential matters." MCKEJVEY, EvIDENCE (3d ed. 1924) 423, note 19.

1624 WiGMIORE, EVIDENCE (2d ed. 1923) §2228.

1031 GreenteAF, Evidence (16th ed. 1899) §333c: The privilege as to confidential communications "has never been and probably never will be infringed upon. It is one which no one is likely ever to propose to abolish."

1645 WigMoRe, EVIDENCE (2d ed. 1923) \$2332.

165 JoNEs, EvIDENCE (3d ed. 1924) 8747 . See also on the rights of a married woman (1928) 13 Iowa L. REv. 481.

I66 SCHOULER, HUSBAND AND WIFE (1882) $\$ 85$.

1071 GreENLEAF, Evidence (16th ed. 1899) \$254. 
are these "hallowed" confidences the kind that are ever involved in litigation? "Would the admission of a husband to his wife that he had committed a crime be such a 'sacred and hallowed' confidence that principles of public policy slould be invoked to protect it? Could an admission by a husband to his wife that he had injured another by negligence, or that he owed his neiglibor' a debt, be tortured into a 'sacred and hallowed confidence"?"168 Even if the sentiment behind the expression "sacred and hallowed confidence" were conceded to be sound, confidences of such a nature will seldom if ever become material points of inquiry in litigation. Hence confidence of the sort necessary to the relation is sufficiently preserved though communications relevant to litigated questions may be brought into evidence.

Secondly, "the relation is a proper object of encouragement by the law." The attack made by Dean Wigmore himself upon the privilege as to anti-marital testimony furnishes here in its application to criminal cases an exceedingly strong argument: ${ }^{160}$ the confidence sought to be protected is that of the wrongdoer himself. It is hardly doubted that at the present time the presumption of innocence is one contrary to fact, that the great bulk of accused persons actually brought to trial are guilty. In view of the alarming present day increase in crime, it becomes doubly true that "no asylum ought to be opened for criminals; every sort of confidence among them must be destroyed if possible, even in the interior of their own houses."170 The marriage relation of criminals deserves no encouragement serving to protect them in the perpetration of their crimes.

The same argument applies, if with somewhat diminished force, to civil cases. The usual inference from the suppression of testimony has undoubtedly a logical core factually. Thus a claim of privilege usually operates to exclude relevant testimony against the one claiming the privilege. The confidence of those using the marriage relation to shield their infringement of the legal rights of others deserves slight encouragement. It should be sufficient that the confidence of the marriage relation will receive no discouragement so long as legitimate ends are in view.

Thirdly, "the injury that would inure to it by disclosure is probably greater than the benefit that would result in the judicial investigation of truth." This is a main point of rehance for supporters of the privilege..$^{171}$ The difficulty, as much in support as in attack of the privilege, lies in the absolute impossibility of determining the injury from disclosure of such

168 Whipple, The Legal Privilege of Concealing the Truth, 1922 MD. BAR REP. 181.

1694 WIGMORE, EVDENCE (2d ed. 1923) \$2228.

170 Bentham, Treatise on Judictal Evidence (Dumont, 1825) Bk. VII. 238.

171 StaRkIE, Evidence (10th Amer. ed. 1876) 38. 
communications. ${ }^{172}$ A rule of exclusion of evidence should not be based upon such an unknown probability or conjecture. If the injury is merely "probably" greater than the benefit, the evidence, otherwise relevant and admissible, should be admitted.

The numerous exceptions to the privilege made from time to time by the legislature have failed to disclose the "probable" injury predicted. These exceptions, based usually on some principle of necessity, are made, it is submitted, because the benefit from the disclosure is exceptionally great, not because the injury will be any the less. ${ }^{173}$ Hence the injury if existent should have made itself apparent.

That marital confidences would not be inhibited through fear of judicial disclosure appears in another way. "This rule of privileged communications is necessary in order that at all time there may be the utmost confidence by one spouse in the other, so that either may know that whatever is communicated by one will be kept inviolable by the other forever, so far as the process of justice in the courts is concerned."174 The policy so stated slows the weakness of its fundamental postulate: that the husband and wife will know whether or not they will be compellable witnesses as to communications, and will act upon this supposed knowledge with a feeling of security. The truth is that a comparative handful of laymen would know of the privilige and base any action on it whatever. The actual disclosure which would ensue in court would be neither anticipated by the parties nor regarded as a voluntary breach of confidence by either. Thus the abolition of the privilege could hardly give rise to a substantial tendency toward marital secretiveness and failure of confidence.

That the disclosure will result in a benefit to the judicial investigation of truth seems to be the opinion of the courts. The possible judicial exception for business communications would go far toward abolition of the privilege in civil cases. The cases allowing testimony of a third person, however lis knowledge of the communications may have been obtained, show the courts' realization of the value of this evidence. The extension of waiver in fraudulent transfer cases likewise illustrates the necessity of obtaiming such evidence in order to administer complete justice.

The California State Bar has taken at least a step toward abolition of the present privilege. The Committee on Practice in Superior Courts, Joln Perry Wood, chairman, issued in 1929 a bulletin to the Sections

172 See to similar effect on privilege as to anti-marital testimony, MORGAN, THE Law of Evidence. SoMTe Proposals for ITS ReForar (1921) Xv.

1735 WigMore, EvIDENCE (2d ed. 1923) \$2338.

174 I EutrotT, EvIDENCE (1904) \$629. 
of the State Bar submitting the "removal of the right of privilege existing in relation to communications between husband and wife."175

\section{E. General Conclusions}

At present all privileges surrounding the testimony of husband and wife are being whittled away by frequent code amendments and by judicial decision. Thus a maze of technicalities and of anomalous rules surrounds and will continue increasingly to surround the application of these privileges. An out-and-out abolition of the privileges, of more than doubtful benefit as they are, demands to be made. The sooner an enlightened legislature acts, the smoother will be the path of justice and the rougher the path of the wrongdoer.

Frederick E. Hines.

THE LaW ScHOor, STANFORD UNIVERSTTY.

175 (Aug. 1929) State Bar Jour. 31. The Alameda Section had already recommended the removal of the privilege. 